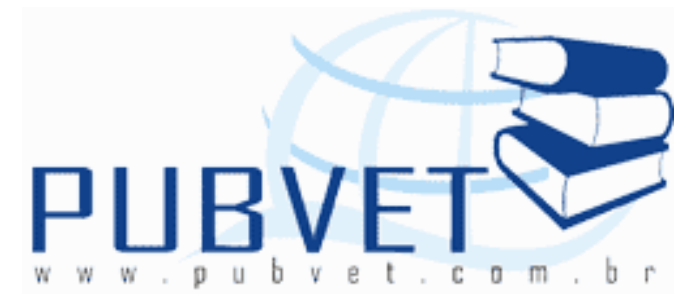

PUBVET, Publicações em Medicina Veterinária e Zootecnia.

\title{
Qualidade do leite na bovinocultura leiteira
}

\section{Anderson Parra de Araujo ${ }^{1}$, Vagno Júnior de Oliveira ${ }^{1}$, Joab Vinícius Martins de Siqueira ${ }^{2}$, Claudio Jonasson Mousquer ${ }^{3}$, Lucien Bissi da Freiria ${ }^{3}$, Mérik Rocha Silva $^{3}$, Verônica Bandeira Ferreira ${ }^{3}$, Amorésio Souza Silva Filho ${ }^{3}$, Crislaine Messias de Souza Santos ${ }^{4}$}

${ }^{1}$ Zootecnista, Universidade do Estado de Mato Grosso, Campus Universitário de Pontes e Lacerda

${ }^{2}$ Agrônomo, Universidade do Estado de Mato Grosso,

3 Mestrandos em Ciência Animal, Universidade Federal de Mato Grosso, Campus Cuiabá

4 Professora, Instituto Federal de Educação, Ciência e Tecnologia de Roraima. crislaine_zoo@hotmail.com.

\section{Resumo}

O setor lácteo é de grande importância econômica e social para o Brasil, sendo fonte de renda para milhares de produtores, e responsável por um dos principais insumos na produção de alimentos essenciais em todas as fases da vida das pessoas, e assim a produção mundial de leite de vaca vem crescendo nos principais continentes. Visto isso, o referente trabalho tem como objetivo fazer uma revisão da qualidade de leite na bovinocultura leiteira. A produção de leite deve obter padrões de exigências para ter um leite de qualidade adequada ao consumo em termos nutricionais, devido à qualidade ser afetada 
ARAÚJO, A.P. et al. Qualidade do leite na bovinocultura leiteira. PUBVET, Londrina, V. 7, N. 22, Ed. 245, Art. 1620, Novembro, 2013.

por vários fatores associados ao manejo, à sanidade, à alimentação, ao potencial genético e a fatores associados à ordenha e ao armazenamento. Com isso a produção de leite deve ter atenção dobrada desde a fazenda até o produto final na indústria.

Palavras-chave: alimentação, exigências nutricionais, produtores, sanidade

\title{
Milk quality in dairy cattle
}

\begin{abstract}
The dairy sector is of great social and economic importance to Brazil, a source of income for thousands of producers, and responsible for one of the main inputs in the production of staple foods at all stages of people's lives, and so the world production of cow's milk has been growing in all major continents. As such, the related work aims to review the quality of milk in dairy cattle. Milk production should obtain standards requirements to have an adequate quality of milk consumption in nutritional quality due to be affected by several factors associated with the management, the health, food, and potential genetic factors associated with the milking and the storage. With that milk production should double attention from the farm to the final product in the industry.
\end{abstract}

Keywords: feed, requirements, nutritional, producers, sanity.

\section{INTRODUÇÃO}

O Brasil atualmente ocupa o $5^{\circ}$ lugar no mundo em produção de leite e se desenvolve a uma taxa de $4 \%$ superior à de todos os países que ocupam os primeiros lugares. Nos últimos dez anos, apresentou crescimento superior a 70\%, fechando o ano de 2009 com 29.112 .000 milhões de litros de leite. Tal avanço foi percebido tanto pelo real aumento na produção, quanto maior registro do volume inspecionado, mas esse valor não registra a real produção de leite brasileira, que conta com a quantidade de leite informal comercializada (BRASIL, 2011). 
ARAÚJO, A.P. et al. Qualidade do leite na bovinocultura leiteira. PUBVET, Londrina, V. 7, N. 22, Ed. 245, Art. 1620, Novembro, 2013.

O setor lácteo é de grande importância econômica e social para o Brasil, sendo fonte de renda para milhares de produtores. Segundo a Secretaria de Desenvolvimento Econômico Social, no ano de 2009, foram ordenhadas 21.900 milhões de vacas, ação que resultou numa produtividade na ordem de 1.307 litros por animal neste período, e que coloca o Brasil entre os maiores produtores de leite do mundo (DEITOS, 2010).

A atividade leiteira é responsável por um dos principais insumos na produção de alimentos essenciais em todas as fases da vida das pessoas. $O$ leite compõe uma das principais fontes de proteína na alimentação humana, sendo o seu consumo incentivo em prol de uma vida saudável (BIEGER, 2010).

Obter leite de qualidade adequada ao consumo em termos nutricionais e de segurança do alimento depende, cada vez mais, de um processo de produção controlado em todas as etapas, desde a formação do rebanho até a entrega do leite para a usina de beneficiamento. Prevenir contaminações e assegurar a higiene do leite requer equipamentos e instalações apropriadas e procedimentos, controles e práticas de trabalho realizado de modo sistemático, por pessoal qualificado e, sobretudo consciente de sua responsabilidade e comprometimento em contribuir para garantir sua qualidade (LIMA, 2004).

A qualidade do leite pode ser afetada por vários fatores associados ao manejo, à sanidade, à alimentação, ao potencial genético e a fatores associados à ordenha e ao armazenamento do leite. Contudo, uma das principais causas da queda da qualidade do leite e das perdas quantitativas na produção é a mastite, doença que provoca maior prejuízo à pecuária leiteira no Brasil e em grande parte do mundo (ANDRADE et al., 2007).

A qualidade do leite é definida por seus parâmetros físico-químicos e microbiológicos. A presença de teores de proteínas, gordura, lactose, sais minerais e vitaminas determinam a manutenção das características do leite, que, por sua vez, é influenciada pela saúde do úbere da fêmea, alimentação, manejo, genética, estágio de lactação e por situações de estresse do animal (GRACINDO e PEREIRA, 2009). 
ARAÚJO, A.P. et al. Qualidade do leite na bovinocultura leiteira. PUBVET, Londrina, V. 7, N. 22, Ed. 245, Art. 1620, Novembro, 2013.

A presença de certos micro-organismos e suas toxinas constitui as causas mais freqüentes de problemas sanitários relacionados aos produtos lácteos. 0 leite e seus derivados, consumidos por muitos, não sofrem qualquer tipo de tratamento térmico como a esterilização e a pasteurização, podendo conter grandes quantidades de toxinas e micro-organismos capazes de causar intoxicação alimentar. Tal fato deve ser levado em consideração, principalmente porque os maiores consumidores de leite são crianças e idosos (MILLER, 2008).

A qualidade do leite e seus derivados estão, de forma crescente, ganhando importância em toda cadeia produtiva dessa atividade, englobando também o consumidor, cada vez mais atento a qualidade dos produtos que adquire, que associada ao preço, determinam a competitividade do produto no mercado (ABREU, 2005).

Diante do exposto, este trabalho tem como objetivo realizar revisão de literatura sobre os fatores que influenciam a qualidade do leite da bovinocultura leiteira.

\section{Mercado do leite no mundo, no Brasil e em Pontes e Lacerda}

A produção mundial de leite de vaca vem crescendo nos principais continentes, atingindo no ano de 2009, uma produção anual de 583.401.740 milhões de toneladas, o que representa aumento de $19 \%$ em apenas uma década (2000 - 2009). Os Estados Unidos ocupam isolada primeira posição, com 85.859 .400 milhões de toneladas/ano, $14,6 \%$ do volume total produzido mundialmente. Em seguida está a Índia, com uma produção anual de 45.140.000 milhões de toneladas, representando $7,7 \%$ do total produzido mundialmente. O Brasil é o quinto maior produtor mundial de leite de vaca, com uma produção de 29.112 .000 milhões de toneladas, representando 4,9\% do volume total produzido mundialmente (BRASIL, 2011).

O crescimento histórico da produção é de aproximadamente 1,5\% ao ano e os países em desenvolvimento vem ganhando participação frente aos 
ARAÚJO, A.P. et al. Qualidade do leite na bovinocultura leiteira. PUBVET, Londrina, V. 7, N. 22, Ed. 245, Art. 1620, Novembro, 2013.

desenvolvidos. Os países asiáticos foram os que mais aumentaram participação na oferta, sobretudo China e Índia. Por outro lado, o continente Europeu vem perdendo participação de mercado, com destaque para os países da parte oriental como Rússia e Ucrânia (CARVALHO et al., 2008).

A China é atualmente o maior comprador mundial de lácteos e importou, em 2009, o equivalente a 3,3 bilhões de quilos de leite. Outros países com importação superior a 2,0 bilhões de quilos são a Federação Russa, Argélia, México e Arábia Saudita. A Europa e a Oceania são os grandes exportadores de lácteos. Mais da metade do volume exportado é proveniente da Nova Zelândia e da União Européia, sendo que somente a Nova Zelândia exportou 12,8 bilhões de quilos de leite (HEIDEN, 2010).

O aumento no comércio internacional é visível ao analisarmos os números mundiais da produção de leite de vaca com os das exportações de alguns lácteos. Contudo, o crescimento do setor lácteo e a demanda por seus produtos sugerem que o mercado internacional de lácteos permanecerá favorável, assim como pouco serão os países capazes de acompanhar este crescimento com condições de competitividade internacional (PADILHA, 2006).

A partir do século $X X$, com a criação da Organização Mundial de Saúde (OMS) estabeleceu-se como recomendação o consumo per capita médio anual de 175 litros de leite. O consumo médio, em equivalentes litros de leite, nos países ricos ocidentais, na Argentina e no Uruguai, é superior a 200 litros por habitante/ano. No Brasil, o consumo per capita médio é inferior a 130 litros/ano, abaixo do preconizado pela OMS (MARTINS, 2004).

De acordo com Simionato (2008), o setor leiteiro destaca-se como um dos sistemas agroindustriais com maiores perspectivas de crescimento, tamanha sua importância econômica e social para o país, uma vez que é praticado em todo território nacional.

Segundo Vilela (2001), a característica marcante na produção leiteira no Brasil é a grande diversidade existente, associada a fatores regionais, devido à grande dimensão territorial. Outra característica é a distribuição assimétrica dos produtores na cadeia produtiva, onde um número elevado de pequenos 
ARAÚJO, A.P. et al. Qualidade do leite na bovinocultura leiteira. PUBVET, Londrina, V. 7, N. 22, Ed. 245, Art. 1620, Novembro, 2013.

produtores tem baixa participação na produção total nacional e alguns poucos grandes produtores participam em grande escala dessa produção, com a tendência dessa situação se agravar ainda mais.

Esta situação é confirmada por Martins (2004), ao concluírem que $80 \%$ dos produtores são responsáveis por somente $20 \%$ da produção nacional, enquanto que $20 \%$ dos maiores produtores respondem por $80 \%$ da produção nacional. $O$ que se percebe é a tendência do setor em aumentar a escala, melhorar a produtividade e a qualidade do produto.

A produção de leite no Brasil hoje é dominada pela região Sudeste, com $36 \%$ da produção nacional, seguidas pelas regiões Sul (31\%) e Centro-oeste (14\%). O Nordeste detém 13\% da produção e o Norte 6\% (BRASIL, 2010).

No ano de 2009, o Estado de Minas Gerais produziu 27,2\% de leite do total nacional, seguido pelo Rio Grande do Sul com 11,6\% (BRASIL, 2011). De acordo com Brasil (2011), Mato Grosso, no ano de 2009, ocupou a décima colocação com uma produção de 680.589 mil litros de leite, representando $2,3 \%$ do total produzido nacionalmente, e teve aumento de $3,7 \%$ em relação ao ano de 2008. De acordo com os dados do Brasil (2010), Pontes e Lacerda, no ano de 2009, apresentou produção de 26.232 litros de leite com aumento de $0,44 \%$ em relação ao ano de 2008 .

\section{CLASSificaÇÃo do LEITE NO BRASIL}

Devido a grandes problemas com a qualidade do leite no Brasil, foi necessária a criação da Instrução Normativa n० 51 (IN n 51) através do Ministério da Agricultura Pecuária e Abastecimento (MAPA), publicada no Diário Oficial da União em 18 de setembro de 2002, por intermédio do Departamento de Inspeção de Produtos de Origem Animal (DIPOA). Essa Instrução Normativa é importante para fiscalizar e monitorar a qualidade do leite produzido no país, e regulamenta a produção, identidade, qualidade, coleta e transporte do leite, visando atender o consumidor com produto de maior qualidade (BRANCO 2010). 
ARAÚJO, A.P. et al. Qualidade do leite na bovinocultura leiteira. PUBVET, Londrina, V. 7, N. 22, Ed. 245, Art. 1620, Novembro, 2013.

O leite é classificado de acordo com sua produção, composição e requisitos físico-químicos e biológicos, e assim recebem a classificação de leite tipo A, B, ou C (Tabela 1). Essas classificações são determinadas a partir da contagem de micro-organismos presentes no leite e, de forma geral, para cada tipo de micro-organismo existem métodos específicos para sua determinação na classificação do leite (VENTURINI, 2007).

Tabela 1: Classificação dos tipos de leite conforme a legislação brasileira

\begin{tabular}{|c|c|c|c|}
\hline Tipo & A & B & C \\
\hline $\begin{array}{l}\text { Carga bacteriana } \\
\mathrm{col} / \mathrm{ml} \text { (leite } \mathrm{cru} \text { ) }\end{array}$ & 10.000 & 500.000 & Sem limites \\
\hline $\begin{array}{l}\text { Carga bacteriana } \\
\mathrm{col} / \mathrm{ml} \\
\text { (pasteurizado) }\end{array}$ & 5.000 & 40.000 & 150.000 \\
\hline Coliformes & $\begin{array}{c}\text { Ausência em } \\
11 \mathrm{ml}\end{array}$ & $\begin{array}{c}\text { Tolerância em } \\
0,5 \mathrm{ml}\end{array}$ & $\begin{array}{c}\text { Tolerância em } \\
0,2 \mathrm{ml}\end{array}$ \\
\hline $\begin{array}{l}\text { Matéria gorda } \\
(\% \mathrm{~m} / \mathrm{v})\end{array}$ & Integral & Integral & 3,0 \\
\hline Acidez (dormic) & $15-18$ & $15-18$ & $15-18$ \\
\hline Densidade $(\mathrm{g} / \mathrm{l})$ & $\begin{array}{c}1.028- \\
1.033\end{array}$ & $1.028-1.033$ & $1.028-1.035$ \\
\hline Crioscopia $(\mathrm{H})$ & $\begin{array}{c}-0,54 a- \\
0,56\end{array}$ & $-0,54 a-0,56$ & $-0,54 a-0,56$ \\
\hline Alizarol $\left(68^{\circ} \mathrm{GL}\right)$ & Normal & Normal & Normal \\
\hline Lactose $(\% \mathrm{~m} / \mathrm{v})$ & 4,3 & 4,3 & 4,3 \\
\hline Fosfatase & + & + & + \\
\hline Peroxidade & + & + & + \\
\hline
\end{tabular}

Fonte: Adaptado de Venturini (2007)

O leite tipo A é o que contém menos de 10.000 micro-organismos $/ \mathrm{ml}$ de leite $\mathrm{cru}$, enquanto o $\mathrm{B}$ pode apresentar até 500.000 microorganismos $/ \mathrm{ml}$ e o C, mais de 500.000 microorganismos/ml (BALBINI e BUTUGAN, 2001).

Leite tipo A provém de ordenha mecânica diretamente ligada ao resfriador, sem entrar em contato com o meio externo, contendo no mínimo $3 \%$ de proteína e $2,9 \%$ de gordura (PALES et al., 2005). Quanto à composição microbiológica, há requisitos para o leite cru resfriado tipo $A$ integral e para o leite pasteurizado tipo $A$. O leite cru refrigerado tipo $A$ integral deve apresentar 
ARAÚJO, A.P. et al. Qualidade do leite na bovinocultura leiteira. PUBVET, Londrina, V. 7, N. 22, Ed. 245, Art. 1620, Novembro, 2013.

número máximo de $10.000 \mathrm{UFC} / \mathrm{ml}$. O leite pasteurizado tipo A é avaliado desde a pasteurização até a saída do estabelecimento industrial produtor e pode ser observado na CBT (contagem bacteriana total) número máximo de $1.000 \mathrm{UFC} / \mathrm{ml}$ (KLOSS et al., 2010).

O leite tipo B é oriundo de ordenha manual ou mecânica, refrigerado logo após a ordenha, atingido a temperatura máxima de $70 \mathrm{C}$ até três horas após acondicionamento no resfriador. A permanência na propriedade é de no máximo 48 horas após a ordenha e o leite deve conter no mínimo 3\% de proteína e 2,9\% de gordura (PALES et al., 2005).

Na composição microbiológica do leite tipo $B$, há requisitos para o leite cru refrigerado do tipo $B$ integral e do leite pasteurizado tipo $B$. O leite cru refrigerado tipo $B$ integral deve apresentar número máximo de 500.000 $\mathrm{UFC} / \mathrm{ml}$. O leite pasteurizado tipo B integral é avaliado desde a pasteurização até a saída do estabelecimento industrial produtor, podendo ser observado na CBT número máximo de 80.000 UFC/ml (KLOSS et al., 2010).

O leite tipo $C$ é oriundo de ordenha manual, mas que não sofre nenhum tipo de tratamento na propriedade, sendo entregue no laticínio até as 10 horas da manhã do dia da ordenha, contendo no mínimo 3\% de proteína e 2,9\% de gordura (PALES et al., 2005). Na microbiologia do leite tipo C, há requisitos para o leite cru refrigerado tipo $\mathrm{C}$ integral e do leite pasteurizado tipo $\mathrm{C}$. O leite cru refrigerado tipo $C$ integral não possui limite máximo para UFC/ml. O leite pasteurizado tipo C é avaliado desde a pasteurização até a saída do estabelecimento industrial produtor, observando-se na CBT número máximo de 300.000 UFC/ml (KLOSS et al., 2010).

O leite de menor volume produzido no Brasil é tipo $A$, e é o mais caro devido as normas que exigem industrialização do leite totalmente na fazenda, o que requer maior investimento, e conseqüentemente maior custos para produzi-lo. O leite tipo B apresenta segunda posição em produção e tem os padrões de exigências de produção do leite tipo $A$, mas o leite tipo $B$ pode ser transportado e industrializado nas empresas, e não necessariamente na fazenda produtora. Já o leite tipo C é o de maior produção no Brasil, pois é o 
ARAÚJO, A.P. et al. Qualidade do leite na bovinocultura leiteira. PUBVET, Londrina, V. 7, N. 22, Ed. 245, Art. 1620, Novembro, 2013.

insumo principal na fabricação do leite UHT e dos produtos lácteos disponíveis no mercado, além de não possuir as exigências, seguidas pelo leite $A$ e $B$ (PEDRA, 2008).

\section{Fatores que Afetam a Composição e a Qualidade do Leite}

A produção de leite, como os outros segmentos da atual sociedade, é uma atividade cada vez mais competitiva. Portanto, é importante quantificar e qualificar os fatores que podem influenciá-la, buscando ganhos efetivos na quantidade e qualidade do leite produzido, na tentativa de produção de leite de maior qualidade para os consumidores (COLDEBELLA et al., 2004).

De acordo com Gonzáles (2001), a composição média do leite pode variar em função de vários fatores como raça, estágio da lactação, idade do animal, estação do ano, alimentação e a saúde da glândula mamária. São vários os componentes do leite, sendo que a água representa a maior proporção e os demais constituintes são, principalmente, a gordura, a proteína e a lactose, todos sintetizados na glândula mamária (Tabela 2).

Tabela 2: Composição do leite de vaca

\begin{tabular}{cc}
\hline Componentes principais & Composição média \\
\hline Água & $87 \%$ \\
Sólidos totais & $13 \%$ \\
Gordura & $3,9 \%$ \\
Proteínas & $3,4 \%$ \\
Lactose & $4,8 \%$ \\
Minerais & $0,8 \%$ \\
\hline
\end{tabular}

Fonte: Adaptado de Venturini (2007)

As proteínas representam entre $3 \%$ e $4 \%$ dos sólidos encontrados no leite de vaca e, quanto maior a porcentagem de gordura no leite, maior será a de proteína. A gordura é o componente que mais apresenta variação (3 - 9\%) e pode ser influenciada por uma série de fatores nutricionais que interagem entre si como a quantidade e qualidade da fibra fornecida e a proporção 
ARAÚJO, A.P. et al. Qualidade do leite na bovinocultura leiteira. PUBVET, Londrina, V. 7, N. 22, Ed. 245, Art. 1620, Novembro, 2013.

volumoso/concentrado da dieta. Desta forma, a alimentação balanceada e com ingredientes de boa qualidade podem afetar de forma positiva a porcentagem de gordura e proteína do leite produzido (PASCHOAL, 2010).

Conforme Fagundes (2005), o critério básico adotado para o programa de pagamento por qualidade é a composição do leite. O sistema de preço do litro de leite é abandonado e é adotado um preço por quilograma de gordura, por quilograma de proteína, por quilograma de lactose, considerando-se que os cuidados básicos de higiene (CBT) e sanidade (CCS) sejam atingidos.

A atividade leiteira no Brasil considera o teor de gordura do leite a característica produtiva mais enfatizada pelos serviços de controle leiteiro, considerando os sistemas de pagamento do leite com base no volume e no conteúdo de gordura. Em alguns países como Holanda, Dinamarca, Polônia e Suíça, desde o início da década de 80, a maior importância por pagamento por qualidade tem sido dada para proteína do leite. O teor de proteína e a qualidade do leite são importantes principalmente para fabricantes de queijos, por serem fatores determinantes da qualidade e do rendimento do produto (CORRÊA, 2010).

Machado (2008) cita que no Brasil algumas empresas estão adotando o pagamento por qualidade do leite produzido, pagando-se um preço base e um adicional por volume, mercado, distância, teor de proteína, teor de gordura, e concentração de células somáticas e bactérias. A bonificação para o leite com $3,5 \%$ de gordura, 3,2\% de proteína bruta, 250 mil células $/ \mathrm{ml}$ e $70 \mathrm{UFC} / \mathrm{ml}$ seria equivalente a $\mathrm{R} \$ 0,03 /$ litro de leite (Tabela 3 ).

Tabela 3: Esquema de pagamento por qualidade do leite de uma empresa brasileira

\begin{tabular}{lcc}
\hline Parâmetros & Bonificação & Punição \\
\hline Proteínas (\%) & Acima de 3,0 & Abaixo de 2,9 \\
Gordura $(\%)$ & Acima de 3,25 & Abaixo de 3,05 \\
CSS $(x$ mil céls $/ \mathrm{ml})$ & Abaixo de 400 & Acima de 500 \\
CBT $(x$ mil ufc $/ \mathrm{ml})$ & Abaixo de 150 & Acima de 450 \\
\hline
\end{tabular}

Fonte: Adaptado Machado (2008) 
ARAÚJO, A.P. et al. Qualidade do leite na bovinocultura leiteira. PUBVET, Londrina, V. 7, N. 22, Ed. 245, Art. 1620, Novembro, 2013.

Gracindo e Pereira (2009) comentam que seria viável também o pagamento por sólidos totais do leite, visto que $64,4 \%$ do leite produzido no Brasil são utilizados de forma fluida e o restante na produção de derivados, que é totalmente dependente desse parâmetro. Com isso os produtores teriam maior incentivo na produção. Desta forma, o pagamento por qualidade se tornaria uma ferramenta importantíssima no estímulo ao setor leiteiro, promovendo a participação mais efetiva do produtor em se empenhar em adotar medidas sanitárias no processo de melhoria da qualidade do leite.

\section{Fatores nutricionais que alteram a composição do leite}

A composição do leite é determinante para o estabelecimento da sua qualidade nutricional e adequação para processamento e consumo humano. A biossíntese do leite ocorre na glândula mamária, sob controle hormonal. Muitos dos constituintes são sintetizados nas células secretoras e alguns são agregados ao leite diretamente a partir do sangue e do epitélio glandular. Estima-se que o leite possua em torno de 100 mil constituinte distintos, embora a maioria deles não tenha sido identificados, sendo os principais constituintes a água, lactose, gordura, substâncias minerais e ácidos orgânicos (FREIRE, 2006).

A alimentação é, sem dúvida, fator base para qualquer ramo da produção animal e na bovinocultura de leite não seria diferente, podendo até dizer que "o leite entra pela boca do animal". A composição da ração das vacas lactentes influencia diretamente na constituição do leite produzido. Se há excesso de algum nutriente na alimentação, como por exemplo, proteína, isto poderá ocasionar aumento na proteína bruta do leite, diminuindo a qualidade do leite, pois o excesso de proteína pode ser excretado na forma de uréia, provocando gostos e cheiro estranho no leite, por isso deve se ter uma dieta balanceada para vaca leiteiras, obtendo um consumo adequado de acordo com a produção e mantendo uma a qualidade de leite produzido (PALES et al., 2005). 
ARAÚJO, A.P. et al. Qualidade do leite na bovinocultura leiteira. PUBVET, Londrina, V. 7, N. 22, Ed. 245, Art. 1620, Novembro, 2013.

Segundo Corassin (2006), os alimentos fornecem os precursores diretos e indiretos dos principais componentes sólidos do leite. Manipulações nutricionais, tal como privação alimentar severa, ou utilização de certos suplementos alimentares, são capazes de ocasionar variações imediatas na composição do leite. Em geral, quando através da nutrição, aumentam-se proporcionalmente as quantidades de gordura, proteína e lactose do leite obtemos aproximadamente o mesmo aumento no volume de leite produzido. Devido ao aumento na produção de leite fez com que as necessidades energéticas das vacas aumentassem, levando a formulação de dietas com quantidades relativamente altas de concentrados e o fornecimento de quantias adequadas de fibra na dieta para que o rúmen funcione adequadamente e a vaca consiga expressar totalmente seu potencial genético.

A produção de leite em quantidade e qualidade depende principalmente do aporte adequado de proteína e energia na dieta da vaca em lactação. A energia necessária para o metabolismo dos animais ruminantes provém basicamente dos ácidos graxos voláteis (acético, propiônico e butírico) produzidos no rúmen pela fermentação dos diferentes alimentos. Dependendo da composição da dieta, ocorrerá uma variação entre a proporção dos ácidos graxos acético e butírico, que são metabólitos precursores de parte da gordura do leite e do ácido propiônico, que é o precursor da lactose do leite e o responsável pelo volume de leite. Assim, os efeitos do aporte de energia na dieta podem ser variáveis, afetando o teor de gordura, influenciando a quantidade de leite. De modo geral, a subnutrição energético-protéica reduz tanto a quantidade de leite quanto o teor de gordura (MÜHLBACH, 2001).

\section{Gordura}

A gordura é o componente do leite de maior variabilidade, sendo influenciada pela genética dos animais, fatores ambientais e pelo manejo nutricional (CORASSIN, 2004). De acordo com Fontaneli (2001), o teor de gordura oscila de 2 a 3 unidades percentuais e conhecer os fatores desta 
ARAÚJO, A.P. et al. Qualidade do leite na bovinocultura leiteira. PUBVET, Londrina, V. 7, N. 22, Ed. 245, Art. 1620, Novembro, 2013.

variação permite interferir ou corrigir eventuais problemas, principalmente os de ordem nutricional podendo ter um equilíbrio no consumo de gorduras nas dietas.

O efeito nutricional é considerado o fator mais importante que afeta a produção de leite. A nutrição tem influência direta sobre a síntese de sólidos do leite e constitui-se na principal ferramenta por meio da qual, produtores podem alterar a composição do leite, respondendo por até $50 \%$ da variação dos seus teores de gordura e proteína. Além disso, as modificações da composição do leite obtidas com o manejo nutricional são rápidas e efetivas. Por exemplo, a simples alteração da relação volumoso/concentrado da ração pode alterar o teor de gordura do leite em mais de 15\% (DEITOS, 2010).

A utilização de concentrados na dieta de vacas leiteiras que ultrapasse $50 \%$ da dieta reduz o teor de gordura do leite em função de uma alteração na fermentação ruminal. O substrato ruminal com maior proporção de concentrado proporciona uma maior produção de ácidos graxos voláteis que reduzem $0 \mathrm{pH}$ do rúmen para menos de 6,0 acarretando em uma menor degradação de porção fibrosa da dieta. Uma menor digestão de fibra reduz a produção de acido acético, e uma maior digestão de concentrados aumenta a produção de ácido propiônico. Como ácido acético é um dos principais precursores da gordura do leite a sua redução está diretamente relacionada com a diminuição da gordura do leite (KNORR, 2002).

Segundo Fontaneli (2001), a inclusão de lipídios na dieta, ao redor de 5\% a $7 \%$ na MS da dieta, tende a gerar aumento na produção de leite em função de elevação no teor de energia, visto que a gordura é 2,25 vezes mais energéticas do que glicídios e proteínas. A adição de gordura na dieta reduz o teor de proteína do leite em torno de 0,1 a 0,3 unidades percentuais, cerca de 0,07\% para cada $450 \mathrm{~g}$ de gordura adicionada, devido à inaptidão dos microorganismos do rúmen em utilizar a gordura como fonte de energia para seu desenvolvimento, afetando a síntese de proteína microbiana e conseqüentemente o fornecimento de aminoácidos para a composição de proteína do leite. 
ARAÚJO, A.P. et al. Qualidade do leite na bovinocultura leiteira. PUBVET, Londrina, V. 7, N. 22, Ed. 245, Art. 1620, Novembro, 2013.

\section{Proteína}

A proteína é o segundo componente do leite que varia em função da alimentação, depois da gordura. O consumo limitado de alimento com baixo conteúdo de proteína ou energia na dieta é o principal efeito que causa diminuição do teor de proteína no leite e fatores não nutricionais, como estágio de lactação e estresse térmico, também afetam o teor de proteína do leite (GONZÁLES, et al., 2003).

A composição protéica total do leite reúne varias proteínas específicas. Dentro da proteína, a mais importante é a caseína, que perfaz cerca de $85 \%$ das proteínas lácteas. As caseínas se agregam formando grânulos insolúveis chamados micelas. As demais proteínas do leite estão em forma solúvel. A estrutura granular multimolecular das micelas de caseínas esta composta de várias proteínas similares além da própria caseína, mais água e minerais, principalmente cálcio e fósforo, algumas enzimas também estão associadas às micelas de caseínas. A estrutura micelar da caseína do leite é importante na digestão do leite no estômago e no intestino. Também é a base para os produtos da indústria de laticínios e a base para separar facilmente protéicos de outros componentes do leite (GONZÁLES e CAMPOS 2001).

A caseína é uma fosfoproteina relativamente hidrofóbica encontrada no leite na forma de micelas (denso grânulo de proteína). As micelas de caseínas contem também água e minerais, principalmente cálcio e fósforo. A caseína é um dos mais abundantes componentes orgânicos do leite, junto com a lactose e à gordura. As moléculas individuais de caseína não são muitos solúveis no ambiente aquoso do leite. No entanto, os grânulos da micela de caseína mantêm uma suspensão colóide no leite, se a estrutura micelar se parte, as micelas se dissociam e a caseína fica insolúvel, formando coalho (NORO, 2001).

A proteína do leite tem sido o nutriente mais valorizado em sistemas de pagamento por componentes. A principal razão disto é que, enquanto a gordura tem tido seu valor reduzido pelos hábitos de consumo da população, a 
ARAÚJO, A.P. et al. Qualidade do leite na bovinocultura leiteira. PUBVET, Londrina, V. 7, N. 22, Ed. 245, Art. 1620, Novembro, 2013.

proteína tem sido valorizada principalmente por influir diretamente no rendimento industrial de derivados lácteos (NORO, 2004).

\section{Micro-organismos Presentes no Leite}

$\mathrm{Na}$ atividade leiteira, a microbiologia é muito importante, pois é o principal fator que determina a obtenção do leite de alta qualidade e pode ser definida como a estimativa de contaminação do leite por micro-organismos, que estão diretamente relacionados à saúde do animal e às condições gerais de manejo e higiêne adotados na fazenda (GRACINDO e PEREIRA, 2009)

Segundo Mendes (2006), pode-se afirmar que os principais microorganismos envolvidos com a contaminação do leite são bactérias, sendo que vírus, fungos e leveduras têm uma participação reduzida, apesar de serem potencialmente importantes em algumas situações.

A boa qualidade do leite destinado ao consumo humano é fator de suma importância, visto que o mesmo é considerado uma das principais fontes de nutrientes para grande parte da população. Seu valor está baseado principalmente em seu perfeito balanço de nutrientes, riqueza em minerais e valor energético. Por outro lado, estas características o torna um dos alimentos mais suscetíveis de sofrer alterações físico-químicas e deterioração por microorganismos oriundos de diferentes fontes (KROLOW, 2006).

Ao ser feito a ordenha do animal sadio, já existem alguns microorganismos que penetram nos tetos e saem no leite com a ordenha, e após a retirada do leite pode haver contaminação, posteriormente, durante as operações que segue até o produto final. A quantidade de bactérias, sua importância e seu impacto dependem do tipo de bactéria, da sua ação sobre os componentes do leite, da capacidade de permanecer viável e de multiplicar-se e do tratamento do leite (NAUIACK, 2006).

A contaminação do leite pode ser dividida em endógena e exógena e sua intensidade depende de vários fatores. A contaminação endógena ocorre dentro do úbere da vaca e, nesse caso, os micro-organismos já se encontram 
ARAÚJO, A.P. et al. Qualidade do leite na bovinocultura leiteira. PUBVET, Londrina, V. 7, N. 22, Ed. 245, Art. 1620, Novembro, 2013.

no leite quando o mesmo sai pelo canal do teto, por ocasião da ordenha. A contaminação exógena ocorre após o leite sair do úbere da vaca e pode ser proveniente do exterior da vaca (cauda, pêlos), do próprio ondenhador, do vasilhame, do equipamento e do ambiente. A qualidade higiênica do leite é influenciada principalmente pelo estado sanitário do rebanho, manejo dos animais e dos equipamentos durante e após a ordenha (ABREU, 2005).

\section{Bactérias}

As bactérias são micro-organismos unicelulares que podem sobreviver na água, na poeira, na terra, na palha, no capim, no corpo e pêlos das vacas, nas fezes, na urina, nas mãos do ordenhador, nos insetos e em utensílios de ordenha sujos, mas não necessitam de células vivas para a sua sobrevivência, multiplicando-se rapidamente por divisão celular (ABREU, 2005).

As bactérias que se encontram no leite podem dividir-se em dois grupos: bactérias úteis e bactérias nocivas. As bactérias do ácido láctico (e.g. Streptococcus lactis) são úteis. Elas produzem ácido láctico, que não é nocivo e conferem ao leite gosto fresco, ácido. Além disso, o ácido láctico é bom conservante para os produtos ácidos. As bactérias patogênicas, as que podem causar doenças nos seres humanos, não podem desenvolver-se nos produtos ácidos (EBING e RUTGERS, 2006).

A Contagem Bacteriana Total (CBT) indica a contaminação bacteriana do leite e reflete a higiêne de obtenção e conservação do mesmo. É expressa em unidades formadoras de colônia por mililitro (UFC/mL). De acordo com o Ministério da Agricultura Pecuária e Abastecimento (MAPA), a CBT admitida no leite cru refrigerado é de até $750.000 \mathrm{UFC} / \mathrm{mL}$. As bactérias classificadas como patogênicas são capazes de causar doenças ao homem e são deteriorantes, uma vez que este grupo de bactérias se alimenta dos componentes do leite, alterando-o e tornando-o impróprio para o consumo e para a indústria (PASCHOAL, 2010). 
ARAÚJO, A.P. et al. Qualidade do leite na bovinocultura leiteira. PUBVET, Londrina, V. 7, N. 22, Ed. 245, Art. 1620, Novembro, 2013.

As bactérias podem ser classificadas em três categorias distintas, segundo a faixa de temperatura ótima para o crescimento e multiplicação: bactérias psicrófilas, mesófilas e termófilas. A faixa ótima de crescimento da psicrófilas se encontra de 0 e $15{ }^{\circ} \mathrm{C}$; a da mesófilas entre 20 e $40{ }^{\circ} \mathrm{C}$; e das termófilas entre 44 e $55^{\circ} \mathrm{C}$. Além destas, duas outras categorias de micro-oganismos são importantes, as bactérias psicrotróficas, termodúricas e termófilas. As psicrótroficas, por definição, são aquelas capazes de crescer em baixas temperaturas $\left(<=7^{\circ} \mathrm{C}\right)$, independente da sua temperatura ótima de crescimento. Já as termodúricas correspondem ao grupo de bactérias capazes de resistir ao processo térmico de pasteurização (MENDES, 2006).

\section{Contaminação do Leite}

O leite de vaca merece especial atenção, pois é altamente perecível e largamente consumido pela população, sobretudo consumido pelas crianças. Tudo isso tem chamado atenção das fiscalizações para ter uma produção de leite de qualidade, pois o consumo de leite in natura e produtos lácteos contaminados, causa grande riscos a saúde publica, e os meios de contaminação pode ser desde os animais até o processo de fabricação de produtos lácteos, com isso deve se ter uma conscientização em todo o

processo de produção para garantir a saúde da população (BALBANI e BUTUGAN, 2001).

A qualidade do leite inicia-se na fazenda, sendo necessária ordenha com condições higiênicas e animais saudáveis. $\mathrm{Na}$ industrialização, distribuição e comercialização do leite a qualidade do leite deve ser mantida. A contaminação do leite pode ocorrer de várias maneiras: durante a ordenha, no processamento com equipamentos inadequados, devido à falta de limpeza e higiene dos recipientes, devido ao estado de saúde dos animais, assim como várias outras formas. Alguns fatores como, por exemplo, o estado de saúde dos animais irá atingir de forma direta o ser humano, podendo provocar doenças como a tuberculose, a brucelose e a leptospirose (VENTURINI, 2007). 
ARAÚJO, A.P. et al. Qualidade do leite na bovinocultura leiteira. PUBVET, Londrina, V. 7, N. 22, Ed. 245, Art. 1620, Novembro, 2013.

\section{Água no leite}

A água é elemento essencial na vida dos seres vivos, mas a água contaminada pode causar grandes prejuízos na produção leiteira, prejudicando os animais e conseqüentemente contaminando o leite. A água pode adulterar a qualidade do leite através de águas contaminadas ou até mesmos com adição da mesma no leite, sendo considerado fraude no leite (BLAUW e HERTOG, 2008).

Segundo Freire (2006), a detecção da maioria das fraudes é delicada e exige muita atenção por parte do encarregado que vai efetuar as análises. Uma das principais fraudes é a adição de água no leite, pois não só diminui o valor nutritivo do produto, mas também pode ser fonte de contaminação por agentes patogênicos. Essa agua faz com que o leite congele mais rapidamente, ou seja, congela mais em temperatura mais alta quando comparado a um leite normal, ficando com ponto de congelamento mais próximo da água.

A contaminação microbiológica da água utilizada no processo produtivo leiteiro, por agentes etiológicos tais como protozoários, bactérias e helmintos, à torna veículo transmissor de diversas enfermidades. Pode provocar danos à produção animal em relação à qualidade do produto final, nesse caso específico o leite, consequentemente pondo em risco a saúde humana (BRANCO, 2010).

Nas propriedades rurais é comum o uso de água oriunda de diversas fontes e sem tratamento adequado. No caso, a atividade leiteira demanda grandes volumes e a oferta e as fontes, invariavelmente, estão relacionadas à quantidade de córregos, açudes e ribeirões, e ainda nascentes ou minas, mais fácies de serem utilizadas, porém são mais susceptíveis a contaminações externas. Atualmente a qualidade da água tem sido considerada determinante na busca por melhores resultados na produção, contribuindo para o bem estar dos animais, tornando-os mais sadios e produtivos. Água contaminada pode veicular bactérias causadoras de mastite em vacas e também veicular bactérias que contaminam o leite, podendo provocar acidez e perda do leite (OTENIO et al., 2010). 
ARAÚJO, A.P. et al. Qualidade do leite na bovinocultura leiteira. PUBVET, Londrina, V. 7, N. 22, Ed. 245, Art. 1620, Novembro, 2013.

\section{Contaminação do leite na ocasião da ordenha}

De acordo com Netto (2006), o produtor deve dar importância ao processo de ordenha, pois nesta fase que a vaca dará o retorno esperado da exploração leiteira, portanto os cuidados de higiene devem ser intensos e rigorosos para que os gastos sejam os menores possíveis. Os benefícios econômicos de uma boa ordenha proporcionam aumento na produção, pois vacas sadias produzem mais, e melhor qualidade do leite devido a ausência de condenação do leite na plataforma dos laticínios, menores gastos com medicamentos, mão-de-obra e assistência veterinária. Além disso, reduz a incidência de quartos perdidos, considerados como fonte de contaminação e também fêmeas descartadas em fase das mamites ocorridas no rebanho, mantendo um rebanho saudável, e garantindo uma produção de ótima qualidade e de destaque no mercado.

Segundo Porto (1998), o objetivo da ordenha higiênica é obter leite com a menor carga bacteriana possível, o que garantirá produto de boa qualidade ao consumidor e uma matéria-prima de qualidade para a indústria láctea.

A higiene do animal, do ordenhador e das instalações são ações necessárias para obter leite de qualidade sem contaminação por ocasião da ordenha. Para uma correta higienização, os funcionários devem limpar e desinfetar as instalações e utensílios utilizados, lavar as mãos antes da ordenha, além de no momento da ordenha fazer os testes de mastite e a desinfecção das tetas do animal, secá-las com papel toalha e, após a ordenha, desinfetar novamente as tetas (DÜRR, 2005).

A limpeza do equipamento é tão importante quanto o manejo e higiene da ordenha, sendo fundamental para a qualidade do leite. As principais etapas de limpeza do equipamento constituem-se de enxágue com água morna (32 a $\left.41^{\circ} \mathrm{C}\right)$, enxágue com água e detergente alcalino clorado $\left(71\right.$ a $\left.74^{\circ} \mathrm{C}\right)$, enxágüe ácido e santificação pré-ordenha, deve ser realizado após todas as ordenhas com muito cuidado (MÜLLER, 2002). 
ARAÚJO, A.P. et al. Qualidade do leite na bovinocultura leiteira. PUBVET, Londrina, V. 7, N. 22, Ed. 245, Art. 1620, Novembro, 2013.

\section{Antibióticos no leite}

A presença de resíduos químicos no leite tem agravado sua composição, e sua consequente ingestão pelos seres humanos, tem sido uma das maiores preocupações das populações em adquirir produtos contaminados (FAGAN, 2006).

Os resíduos de drogas veterinárias como antibióticos também podem contaminar o leite. Na maioria dos casos, seus efeitos sobre a saúde do ser humano, em longo prazo, não são conhecidos, mas podem ser responsáveis por fortes reações alérgicas em pessoas sensíveis e provocar resistência aos antibióticos, tornando mais difícil o tratamento de infecção no ser humano, e por essa razão foi recomendado que os antibióticos utilizados na medicina humana não sejam utilizados em animais (MENDES, 2006).

O leite produzido por vacas no período de lactação é obtido através de elementos que passam na corrente sanguínea para células especializadas da glândula mamária, porém neste momento, medicamentos como antibióticos, que tenham sido administrados ao animal para tratamento de doenças, podem passar para o leite. Uma das principais contaminações do leite e através de antibióticos para tratamento de mastite, visto que grande parte do rebanho leiteiro brasileiro é acometido por essa doença. O leite contaminado com substâncias químicas é considerado adulterado e impróprio para o consumo, com isso representa perigo para a saúde, devendo o mesmo ser descartado, causando grande prejuízo à produção leiteira (SILVA, 2009).

Segundo Nero et al. (2007) pesquisaram em propriedades leiteiras de quatro Estados do Brasil, foram coletadas 210 amostras de leite cru e após as análises nas 210 amostras detectaram substâncias de antibióticos em 24 amostras, $(11,4 \%)$, sendo das 24 amostras coletadas 13 foram região de Londrina-PR, e das 24 amostras 20,6\% estava contaminadas com resíduos de antibióticos. Na região de Botucatu-SP de 4 amostras coletadas $8,0 \%$ estava contaminadas, na região de Viçosa-MG das 4 amostras 8,5\% estava contaminadas, e na região de Pelotas-RS das 3 amostras $6,0 \%$ estava 
ARAÚJO, A.P. et al. Qualidade do leite na bovinocultura leiteira. PUBVET, Londrina, V. 7, N. 22, Ed. 245, Art. 1620, Novembro, 2013.

contaminadas. Os resultados obtidos permitem concluir que a presença de resíduos de antibióticos em leite produzido no Brasil pode ser considerada preocupante, e indicam a presença de um perigo químico associado a esse produto.

O tratamento para mastite tem sido o principal responsável pelos resíduos no leite. Mesmo após a aplicação do antibiótico em somente um quarto mamário, ocorre o aparecimento de resíduos no leite nos quartos nos que não foram tratados, isto se deve a absorção do antibiótico, que passa para corrente sanguínea e daí chega aos outros quartos mamários, contaminado todo o leite da vaca (BRITO e LANGE, 2005).

\section{Leite de animais com mastite}

A mastite bovina é uma doença comum na bovinocultura leiteira e com maiores custos de tratamento. A mastite é um processo de inflamação na glândula mamária, causada por agentes infecciosos, químicos, mecânicos ou térmicos, sendo que as bactérias são principais agentes infecciosos responsáveis pelos casos de mastite. A mastite é um dos principais problemas para produtores de leite, tendo em vista os graves prejuízos acarretados, pela diminuição da produção ou pela perda de tetos afetados, por isso a importância que devemos dar a prevenção e controle (VIEIRA, 2010). Estimase que no Brasil ocorram perdas na produção entre $12 \%$ e $15 \%$ e ainda perdas econômicas significantes para indústrias e laticínios devido à baixa qualidade do leite (MENDES, 2006).

A mastite é classificada em clínica, que manifesta a partir do momento que há resposta inflamatória, ocasionado sinais clínicos, como edema, calor, rubor e perda de função, resultando em alterações das características físicas, textura e cor do leite. Na mastite subclínica a glândula não apresenta qualquer alteração de inflamação no úbere e leite tem aparência normal, no entanto, já existem alterações funcionais do úbere, e há aumento das células somáticas (CAVALCANTE et al., 2010). 
ARAÚJO, A.P. et al. Qualidade do leite na bovinocultura leiteira. PUBVET, Londrina, V. 7, N. 22, Ed. 245, Art. 1620, Novembro, 2013.

A mastite ambiental é causada por vários agentes que vivem no ambiente dos animais, em locais como esterco, urina, barro e camas orgânicas. Os patógenos mais frequentes são as bactérias gran negativas como Escherichia coli, Klebsiella sp., Enterobacter sp., Pseudomonas sp. e Proteus sp. Essa mastite caracteriza-se por alta incidência de casos clínicos, geralmente de curta duração, freqüentemente com manifestação aguda e com maior concentração no momento de pré e pós-parto.A maioria dos casos de novas infecções ocorre durante a ordenha, principalmente em situações nas quais ocorrem problemas de manejo durante a ordenha, visto que os patógenos ambientais estão disseminados por todo o ambiente (CAVALCANTE et al., 2010).

Muller (2002) destaca que deve ser dada atenção especial a dieta dos animais, tanto na lactação como no período seco, pois deficiências de vitaminas e minerais pode aumentar a suscetibilidade dos animais a infecções, em especial a mastite. Além disso, a vitamina $A$ e $E$, selênio, cobre e bcarotenos influenciam positivamente na resistência às mastites.

Coentrão et al. (2008) realizaram um trabalho com 2.657 vacas em lactação, com intuito de descobrir o numero de animais com mastite subclínica, foram coletadas 3.987 amostras de leite, foram utilizados 200.000 células $/ \mathrm{ml}$ como ponto de corte para classificar animais provavelmente infectados, das amostras coletadas 2.063 (52\%) apresentaram resultado acima de 200.000 células/ $\mathrm{ml}$. Os principais fatores de risco para ocorrência de mastite subclínica em vacas leiteiras foram as características dos animais, o manejo inadequado, a inexistência de treinamento dos ordenadores, a não utilização de serviços laboratoriais para identificação dos patógenos e o uso de equipamentos de ordenha sem manutenção periódica foram as principais causas da mastite subclínica.

Costa (2010) em trabalho realizado em 12 propriedades leiteiras com um número médio de vacas por propriedade de 50 vacas, e coletadas 306 amostras de leite, com o intuito de saber quais são os micro-organismos isolados no leite dos quartos mamários das vacas. Das 306 amostras de leite 
ARAÚJO, A.P. et al. Qualidade do leite na bovinocultura leiteira. PUBVET, Londrina, V. 7, N. 22, Ed. 245, Art. 1620, Novembro, 2013.

obtidas, Staphylococcus aureus foi o micro-organismo mais isolado $(28,8 \%)$, seguido por Escherichia coli (19,8\%), Enterobacter spp (11,3\%), Pseudomonas spp $(9,4 \%)$, Staphyloccocus coagulase negativo (8,7\%), Streptococcus spp $(8,2 \%)$, Bacillus spp, e Citrobacter spp, $(2,6 \%)$, Alcaligenes faecalis $(1,4 \%)$, Micrococcus spp $(1,2 \%)$, Proteus spp, $(0,9 \%)$, Corynebacterium spp, $(0,7 \%)$, Klebsiela spp, e Providencia spp (0,2\%). Apenas 17 amostras não apresentaram micro-organismos presentes nos quartos mamários.

Segundo Zafalon et al. (2005), em casos de animas com mastite, o leite apresenta qualidade inferior e diminui o rendimento dos seus subprodutos. A forma subclínica da enfermidade não promove sinais visuais de alteração do leite nem da glândula mamária, contudo, pode acarretar alterações no teor de gordura, extrato seco total, extrato seco desengordurado, conteúdo de caseína e em outras características físico-químicas. Além disso, pode influenciar negativamente no número de células somáticas (Tabela 4).

Tabela 4: Alterações da composição do leite associadas com alta contagem de células somáticas

\begin{tabular}{lccccc}
\hline $\begin{array}{l}\text { Componentes } \\
\text { (g/100 ml) }\end{array}$ & \multicolumn{2}{c}{$\begin{array}{l}\text { CCS } \\
\text { (x1000 }\end{array}$} & cel/ml $)$ & & $\begin{array}{c}\text { Razão da } \\
\text { mudança }\end{array}$ \\
\cline { 1 - 5 } Lactose & $<100$ & $<250$ & $500-1000$ & $>10000$ & \\
Caseína & 4,9 & 4,74 & 4,6 & 4,21 & \\
& 2,81 & 2,79 & 2,65 & 2,25 & $\begin{array}{c}\text { Redução } \\
\text { da síntese }\end{array}$ \\
Gordura & 3,74 & 3,69 & 3,51 & 3,13 & \\
\cline { 1 - 4 } Proteína do soro & 0,81 & 0,82 & 1,10 & 1,31 & Passagem \\
& & & & & de sangue \\
Soroalbuminas & 0,02 & 0,25 & 0,23 & 0,35 & \\
Imunoglobulinas & 0,12 & 0,14 & 0,26 & 0,51 & \\
Cloro & 0,091 & 0,096 & 0,121 & 0,105 & \\
Sódio & 0,057 & 0,062 & 0,091 & 0,0 & \\
Potássio & 0,173 & 0,180 & 0,135 & 0,157 & \\
pH & 6,6 & 6,6 & 6,8 & 6,9 &
\end{tabular}

Fonte: Adaptado de Schallibaum, (2001). Citado por Santos (2003).

O tratamento desses animais com mastite deve ser feito imediatamente após a identificação, com finalidade de evitar o aumento de contaminação no 
ARAÚJO, A.P. et al. Qualidade do leite na bovinocultura leiteira. PUBVET, Londrina, V. 7, N. 22, Ed. 245, Art. 1620, Novembro, 2013.

rebanho. Os primeiro passo a ser tomado, é fazer exames laboratoriais para identificar qual germe presente na infecção, e proceder com o tratamento, utilizando-se o antibiótico especifico para o tipo de germe identificado, e respeitar o período de carência do antibiótico para a utilização de leite (CAVALCANTE, 2004).

\section{ACIDEZ DO LEITE}

A acidez é uma característica físico-química e microbiológica produzida pelas bactérias presentes no leite, originadas principalmente no processo de obtenção pouco higiênico. O teste de acidez é um dos mais comumente utilizados pela indústria leiteira e tem grande valor, uma vez que indica se o leite foi mantido em boas condições de controle do desenvolvimento dos micro-organismos mesofílicos. A presença de acidez está correlacionada com o risco de ocorrência de coagulação do leite durante o processamento, já que o leite com maior acidez titulável possui menor estabilidade ao calor (FONSECA e SANTOS, 2000).

O teste de acidez avalia o grau de acidificação ou estado de conservação do leite, separando o leite normal do leite anormal (Ácido), impróprio para o consumo ou mesmo para industrialização. O leite se for corretamente resfriado, geralmente não apresentará problemas com acidez, porém, deve ser assegurada higiene e conservação. A acidez é relevante entre os defeitos de qualidade, por sua grande ocorrência nos meses mais quentes do ano. Isso pode ocorrer pelas precárias condições de higiene (RODRIGUES, 2006).

A acidez do leite decorre da presença de ácidos orgânicos fracos, portanto, a simples medida do $\mathrm{pH}$ não permite o cálculo da quantidade de ácido presente. Nos laticínios, a acidez do leite é usualmente expressa em graus Dornic, onde se considera que toda acidez do leite deva-se ao ácido lático. O método consiste na titulação de uma amostra de $10 \mathrm{ml}$ de leite com uma solução de "Soda Dornic" (concentração 0,111 mol/l) na presença de uma solução indicadora alcoólica de fenolftaleína a $2 \%$. Cada 0,1 ml da "Solução 
ARAÚJO, A.P. et al. Qualidade do leite na bovinocultura leiteira. PUBVET, Londrina, V. 7, N. 22, Ed. 245, Art. 1620, Novembro, 2013.

Dornic" é capaz de neutralizar $1 \mathrm{mg}$ de ácido lático e a cada $0,1 \mathrm{ml}$ gasto na titulação denomina-se um grau Dornic. Considera-se normal o leite que possui acidez correspondente a 13-18 ${ }^{\circ}$ Dornic (MAGALHÃES, 2005).

O leite, logo após a ordenha, apresenta reação ácida com a fenolftaleína, mesmo sem que nenhuma acidez, como ácido lático, tenha sido produzida por fermentações. A acidez do leite fresco deve-se à presença de caseína, fosfatos, albumina, dióxido de carbono e citratos. A acidez natural do leite varia entre 0,13 e 0,17 por cento, expressa como ácido lático. A elevação da acidez é determinada pela transformação da lactose por enzimas microbianas, com formação de ácido lático, caracterizando a acidez desenvolvida do leite. Tanto a acidez natural quanto a acidez desenvolvida são quantificadas, simultaneamente, em titulações por soluções alcalinas (SILVA, 1997).

\section{SínDROME do LeIte ANORMAL}

Segundo Brito (2009), a Síndrome do leite anormal é um conjunto de alterações da composição e das propriedades físico-químicas do leite que causam transtornos nos processos de elaboração de derivados lácteos, em seus rendimentos e/ou na sua qualidade final, os quais estão associados a transtornos fisiológicos, metabólicos e/ou nutricionais, com implicações nos mecanismos de síntese e secreção láctea da glândula mamária.

A síndrome do leite anormal (SILA) é considerada fenômeno de causa multifatorial e ainda não é bem identificado em todos os casos. Os desbalanços em energia e proteína associados às características da ração, com implicações no ambiente ruminal e comprometimento do metabolismo geral (acidose), A síndrome aumenta em gado de alto potencial genético e em épocas de estresse nutricional ou calórico. Nos quadros de SILA, as limitações de energia disponível no tecido epitelial mamário afetam a síntese e secreção dos componentes lácteos, fundamentalmente de caseína, lactose e os principais macrominerais implicados nesses processos, sendo o fósforo e magnésio. É 
ARAÚJO, A.P. et al. Qualidade do leite na bovinocultura leiteira. PUBVET, Londrina, V. 7, N. 22, Ed. 245, Art. 1620, Novembro, 2013.

provável que esse fenômeno possa ser potencializado por causas genéticas, associadas aos tipos de caseínas e outras proteínas lácteas (FILHO, 2005).

Deve-se, no entanto, antes de apontar para ocorrência da SILA, destacar outras possíveis causas já descritas de alterações da qualidade do leite como mastite, vacas em final de lactação, vacas velhas o teste do leite deve ser realizado imediatamente após a ordenha deve-se aguardar pelo menos 30 minutos. A ocorrência da SILA esta intimamente ligada a alimentação com pastagens com baixo teor de matéria seca (MS) e altos níveis de nitrogênios solúvel. Algumas das possíveis causas da SILA estão associada as desequilíbrio entre energia e proteína da dieta, baixo consumo da matéria seca, aumento do consumo de carboidratos rapidamente fermentáveis (melaço de cana, cana de açúcar) e diminuição do pH ruminal (SANTOS, 2004).

\section{CONSIDERAÇÕES FINAIS}

A produção de leite deve ser rigorosamente controlada para se obter leite de boa qualidade, onde o mesmo é destinado ao consumo humano. O leite é considerado uma das principais fontes de nutrientes na alimentação de grande parte da população. A qualidade do leite é influenciada por vários fatores associados ao manejo, à sanidade, à alimentação, ao potencial genético e a fatores associados à ordenha e ao armazenamento. Por isso deve-se ter uma conscientização do produtor até o produto final, adotando um manejo adequado desde a ordenha até o produto industrializado, com isso podemos melhorar a qualidade do leite, melhorando o alimento do consumidor.

\section{REFERÊNCIAS}

ABREU, L. R.; leite e derivados, caracterização físico químico qualidade e legislação. Lavras-MG. UFLA, 2005. p. 195-203.

ANDRADE, L. M.; ELFARO, L.; CARDOSO, V. L.; et al.; Efeitos genéticos e de ambiente sobre a produção de leite e a contagem de células somáticas em vacas holandesas. Revista Brasileira de Zootecnia. R. Bras. Zootec., v.36, n.2, p.343-349, 2007. 
BALBANI, A. P. S.; BUTUGAN, O. Contaminação biológica de alimentos. São Paulo, 2001. Disponível em: <http://www.pediatriasaopaulo.usp.br/upload/pdf/541.pdf>. Acesso em: 23 set. 2011.

BIEGER, A.; Caracterização das propriedades leiteiras um estudo na cadeia produtiva da bovinocultura de leite no município de Toledo-PR. 2010. 98p. Dissertação (Mestrado em desenvolvimento regional e agronegócio). Programa de pós-graduação Stricto Sensu em Desenvolvimento Regional e agronegócio. Universidade Estadual do Oeste do Paraná. 2010.

BLAUW, H.; HERTOG, G.; Criação de gado leiteiro. Tradução Rob Barnhoorn. Primeira edição Londrina: Paraná, 2008. 94p.

BRANCO, M. P. C.; Qualidade da água e do leite em propriedades leiteiras no município de amargosa, Bahia. 2010. 58 p. Dissertação (Mestrado em Ciência Animal). Programa De Pós-Graduação Em Ciência Animal, Universidade Federal Do Recôncavo Da Bahia, 2010.

BRASIL. Empresa Brasileira de Pesquisa Agropecuária Gado de Leite. Disponível em: <http://www.cnpgl.embrapa.br/index_.php>. Acessado em: 19/09/2011.

BRITO, A. S.; NOBRE, F. V.; FONSECA, J. R. R.; Bovinocultura leiteira informações técnicas e de gestão. Comunicado técnico. Serviço de Apoio às Micro e Pequenas Empresas do Estado do Rio Grande do Norte, 2009. 320p.

BRITO, M. A. V. P.; LANGE, C. C. Resíduo de antibiótico no leite. Minas Gerais, 2005. Disponível em: <http:www//people.ufpr.br/ freitasjaf/artigos/antibioticoleite.pdf>. Acesso em: 25 set. 2011.

CARVALHO, G. R.; KIRCHMEYER, S. B.; MESQUITA, V. M.; et al. Análise da concentração da produção mundial de leite entre 1992 e 2007 . Embrapa Gado de Leite,Juiz de Fora. 2008. $5 p$.

CAVALCANTE, F. L. Manejo necessário no rebanho leiteiro para uma boa ordenha. Boletim técnico. Rio Branco-AC: Embrapa, 2004. 12p.

CAVALCANTE, R. V.; SANTOS, A. S,; NETO, O. L. S.; et al. Mastite bovina: principais agentes isolados no laboratório de doenças infecto-contagiosas dos animais domésticos/ufrpe. In: $X$ JORNADA DE ENSINO, PESQUISA E EXTENSÃO JEPEX, 2010. Recife. Anais... Universidade Federal Rural de Pernambuco. 2010.

COENTRÃO, C. M.; SOUZA, G. N.; BRITO, J. R. F.; et al. Fatores de risco para mastite subclínica em vacas leiteiras. Arquivo Brasileiro Medicina Veterinária e Zootecnia, v.60, n.2, p.283-288, 2008.

COLDEBellA, A.; MACHADO, P.F.; DEMÉTRIO, C. G. B.; et al. Contagem de células somáticas e produção de leite em vacas holandesas confinadas. Revista Brasileira de Zootecnia, v.33, n.3, p.623-634, 2004.

CORASSIN, C, H.; Avaliação de ferramentas para balanceamento de dietas de vacas em lactação. Revista Científica Eletrônica De Medicina Veterinária. Ano III, n. 6, janeiro de 2006. Disponível em: <http://www.revista.inf.br/veterinaria06/artigos/artigo08.pdf>. Acesso em: 20 set. 2011.

CORASSIN, C, H.; Determinação e avaliação de fatores que afetam a produtividade de vacas leiteiras: aspectos sanitários e reprodutivos. 2004. 81p.Tese (Doutorado em Agronomia) Escola Superior "Luiz de Queiroz", Universidade de São Paulo. 2004. 
CORRÊA, A. M. f.; Variação na produção e qualidade do leite de vacas da raça holandesa em função da ordem de parto. 2010. 21p. Graduação (Monografia apresentada, como parte das exigências para obtenção do título de especialista) Universidade Estadual de Maringá, 2010.

COSTA, A. C. Mastite subclínica: patógenos isolados e respectivasensibilidade antimicrobiana, variação da contagem de células somáticas e fatores de risco. 2010. 89p. Dissertação (Mestrado em Ciência Animal) Universidade Federal De Goiás , 2010.

DEITOS, A. C.; MAGGIONI, D.; ROMERO, D.; produção e qualidade de leite de vacas de diferentes grupos genéticos. Campo Digit@I, v.5, n.1, p.26-33, Campo Mourão, dez., 2010.

DÜRR, J. W. Como produzir leite de alta qualidade. Brasília, 2005. Disponível em: <http://www.google.com.br/url?sa =t\&rct=j\&q=como\%20produzir\%20leite\%20de\%20alta\%20

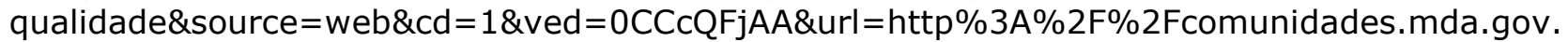
br\%2Fo\%2F892228\&ei=1wHpTtWSKovUgQeSy_TfCA\&usg=AFQjCNHoLI_cghZAgnXR25A5r3zjO tn28w>. Acesso em: 05 set. 2011.

EBING, P.; RUTGERS, K. A preparação de lacticínios. Tradução: Láli de Araújo. 3. ed, São Paulo, 2006. 29p.

FAGAN, E. P. Fatores ambientais e de manejo sobre a composição química, microbiológica e toxicológica do leite produzido em duas granjas produtoras de leite tipo "a" no estado do Paraná. 2006. 96p. Tese (Doutorado em Zootecnia) Programa de Programa de Pós-graduação em Zootecnia. Universidade Estadual de Maringá. 2006.

FAGUNDES, M. H.; Uma nova etapa da Instrução Normativa no 51: a região Centro-Sul. Publicada no Diário Oficial da União. 2002. 22p.

FILHO, D. C. A. Manipulação da composição da gordura no leite. In: SEMINARIO NA DISCIPLINA BIOQUÍMICA DO TECIDO ANIMAL, 2005, Rio Grande do Sul, Anais... Universidade Federal do Rio Grande do Sul, 2005. p. 16.

FONSECA, L.F.L.; SANTOS, M.V. Qualidade do leite e controle de mastite: Lemos Editora, 2000. p. 175.

FONTANELI, R. S.; Fatores que afetam a composição e as características físico-químicos do leite. SEMINARIO NA DISCIPLINA BIOQUÍMICA DO TECIDO ANIMAL, 2001, Rio Grande do Sul, Anais... Universidade Federal do Rio Grande do Sul, 2001.

FREIRE, M. F.; Análises das características físicos químicos do leite cru refrigerado entregue a uma cooperativa no Estado do Rio de Janeiro no ano de 2002. 2006. 23p. Graduação (monografia em especialista em higiene de origem de produtos de origem animal e vigilância sanitária) Curso de pós graduação, Universidade Castelo Branco. Rio de Janeiro, 2006.

GONZÁLES, F. H. D.; DÜR, J. W.; FONTANELI, R. S.; Uso de leite para monitorar a nutrição e o metabolismo de vacas leiteiras. Porto Alegre, 2001. Disponível em: <http://www.comunidades.mda.gov.br/o/892228>. Acesso em: 05 out. 2011.

GONZÁLES, F. H. D; . CAMPOS, R. Indicadores metabólitos nutricionais do leite. In: I simpósio de patologia clinica veterinária da região sul do Brasil. 2003, Porto Alegre. Anais... Porto Alegre: Universidade Federal do Rio Grande do Sul. p. 31-47. 
GRACINDO, A, P. A. C.; PEREIRA, G. F. Produzindo leite de alta qualidade. Rio Grande do Norte, $2009 . \quad$ Disponível em: <http://www.emparn.rn.gov.br/contentproducao/aplicacao/emparn/arquivos/pdf/produzindo\% 20leite\%20de\%20alta\%20qualidade.pdf >. Acesso em: 08 out. 2011.

HEIDEN, F. C. Leite Situação mundial. Santa Catarina, 2010. Disponível em: <http://www.cepa.epagri.sc.gov.br/Publicacoes/Sintese_2010/leite.pdf>. Acesso em: 11 out. 2011.

BRASIL, Instituto Brasileiro de geografia e estatística, da pecuária municipal 2010. Disponível em: http://www.ibge.gov.br/cidadesat/link.php?uf=mt\%20\%3e < acessado em $15 / 09 / 2011>$

KLOSS, A.; BERDNARSKI, F.; OLIVEIRA, K. J.; et al. Leite bovino. In OHI, M.; KNOPKI, A. C. G.; BEDNARSKI, F.; et al. Principios basicos para produção de leite bovino. Curitiba. 2010. p 100-114.

KNORR, M.; O leite como indicador nutricional em vacas. In, SEMINARIO NA DISCIPLINA BIOQUÍMICA DO TECIDO ANIMAL, 2002, Rio Grande do Sul, Anais... Universidade Federal do Rio Grande do Sul, 2002. p. 14.

KROLOW, C.R.; RIBEIRO, M. E. R.; Obtenção de leite com qualidade e elaboração de derivados. Rio Grande do Sul, 2006. Disponível em: <http://www.cpact.embrapa.br/publicacoes/download/.../documento 154.pdf>. Acesso em: 10 set. 2011.

LIMA, L. S.; Modelo de sistemas de gestão da qualidade para propriedades rurais leiteiras. 2004. 142 p. Dissertação (Mestrado em Engenharia de produção), Centro de Ciências Exatas e de Tecnologia, Universidade Federal de São Carlos, 2004.

MACHADO, P. F,; Pagamento por qualidade. In: $3^{\circ}$ CONGRESSO BRASILEIRO DE QUALIDADE DO LEITE, 2008. Recife. Anais... Recife, 2008. P. 230-290.

MAGALHÃES, A. C. M.; Obtenção higiênica e parâmetros de qualidade do leite de cabra. Viçosa-MG, 2005.2 Disponível em: <http://www.cpd.ufv.br/dzo/caprinos/artigos_tec/hig_quali.pdf>. Acesso em: 05 out. 2011.

MARTINS, M. L.; PINTO, C. L. O.; VANETTI, M. C. D.; et al. Detecção de Proteases Bacterianas em Leite por Métodos Imunológicos. Revista do Instituto de Laticínios Cândido Tostes. Juiz de Fora, v. 59, n. 339, p. 61, jul./ago. 2004.

MENDES, M. H. A. F.; Produção higiênica do leite: Boas praticas agrícolas. 2006. 37p. Monografia (Higiene e inspeção de produtos de origem animal). Curso de Pós graduação "Lato Sensu": Higiene e inspeção de produtos de origem animal). Universidade Castelo Branco, 2006.

MILLER, N. B.; Perfil do consumo de leite de derivados lácteos no município de colatinas-ES. 2008. p 72. Graduação (monografia em defesa e vigilância sanitária animal). Programa de pós-graduação QUALITTAS. Universidade Castelo Branco. 2008.

MÜHLBACH, R. F.; Nutrição da vaca em lactação e a qualidade do leite. Boletim técnico. Rio Grande do Sul: Departamento de Zootecnia, 2001. 19p. 
MÜLLER, E. E.; qualidade do leite, células somáticas e prevenção da mastite. In: SIMPÓSIO SOBRE SUSTENTABILIDADE DA PECUÁRIA LEITEIRA NA REGIÃO SUL DO BRASIL, 2002, Maringá. Anais... Universidade Estadual de Londrina, 2002. p. 206-217.

NAUIACK, J. O. Infecções bacterianas mais importantes no leite de vaca. 2006 . p 95. Graduando (monografia em especialista em higiene e inspeção de produtos de origem animal) Programa da Pro - reitoria de pesquisa e pós graduação. Universidade de Castelo Branco. 2006.

NERO, L. A.; MATTOS, M. R.; BELOTI, V.; et al. Resíduos de antibióticos em leite cru de quatro regiões leiteiras no Brasil. Ciências Tecnologia Alimentares. V.27, n.2, p391-393, 2007.

NETTO, F. G. S.; BRITO. L. G.; FIGUEIRÓ, M. R.; Manejo da vaca leiteira. Porto Velho - RO, 2006. Disponível em:

<http://www.cpafro.embrapa.br/media/.../cot319_ordenhadavacaleiteira_.pdf>. Acesso em:

02 nov. 2011.

NORO, G. fatores ambientais que afetam a produção e a qualidade do leite em rebanhos ligados a cooperativas gaúchas. 2004. p 84. Dissertação (Mestrado em Medicina Veterinária) programa de pós-graduação em ciências veterinárias. Universidade Federal Do Rio Grande Do Sul. 2004

NORO, G. Síntese e secreção do leite. In: SEMINARIO NA DISCIPLINA BIOQUÍMICA DO TECIDO ANIMAL, 2001. Rio Grande do Sul, Anais... Universidade Federal do Rio Grande do Sul, 2001. p. 21.

OTENiO, M. H.; CARVALHO, G. L.; SOUZA, A. M.; et al. Cloração de água para propriedades rurais. Minas Gerais, 2010. Disponível em: <http://www.exatta.ind.br//+(11)4062-1888>. Acesso em: 20 set. 2011.

PADILHA, T, F. Bovinocultores leiteiros suas produções, características e perspectivas na região sudeste do Brasil.2006. 79p. Dissertação (Mestrado em Zootecnia), Programa De Pós-Graduação Em Zootecnia, Universidade Federal Rural Do Rio De Janeiro, 2006.

PALES, A. P.; SANTOS, K. J. G. FIGUEIRAS, E. A.; et al. A importância da contagem de células somáticas e contagem bacteriana total para a melhoria da qualidade do leite no Brasil.

Revista Eletrônica Faculdade Montes Belos, Goiás, ISSN 1808-8597, v.1, n.2, p. 162 173, nov. 2005

PASCHOAL, J. J. Instruções técnicas para redução da contagem de células somáticas (CCS) e contagem bacteriana total (CBT). Uberaba-MG, 2010. Disponível em: <http://www.cigeneticabovina.com.br/.../b4212e872b2b2487670e03f1bdd2>. Acesso em: 05 nov. 2011.

PEDRA, D, F. B. M.; PIGATTO, G.; SANTINI, G. A.; analise de fatores produtivos e comerciais da cadeia láctea no Brasil. In: XLVI CONGRESSO DA SOCIEDADE BRASILEIRA DA ECONOMIA, ADMINISTRAÇÃO DA SOCIOLOGIA RURAL, 2008, Tupã. Anais... Tupã: Universidade Estadual Paulista, 2008.

PORTO, E. Microbiologia do leite. 1998. Disponível em: <http://www.esalq.usp.br/departamentos/lan/pdf/TecnologiaLeite.pdf>. Acesso em: 10 out. 2011. 
RODRIGUES, M. S. Revisão de literatura sobre qualidade do leite incluindo a in 51 e mastite bovina. Mineiros, GO: Faculdades Integradas De Mineiros. 2006. 46p. Relatório de Estagio.

SANTOS, M. V. Influencia da qualidade do leite na manufatura e vida de prateleira dos produtos lácteos papel das células somáticas. Juiz de Fora, 2004. Disponível em: <http://www.marcosveiga.net/biblioteca/capitulos/Aspectos\%20nao\%20microb\%20e\%20quali dade\%20do\%20leite.pdf >. Acesso em: 17 set. 2011.

SILVA, P. H. F. Aspectos de Composição e Propriedades. Minas Gerais, 1997. Disponível em: <http://www.qnesc.sbq.org.br/online/qnesc06/quimsoc.pdf>. Acesso em: 20 set. 2011.

SILVA, T. S.; Plano nacional de controle de resíduos e contaminantes em leite (antibióticos). 2009. 26p. Dissertação (Mestrado em Ciência Animal) Programa de PósGraduação em Ciência Animal. Universidade Federal De Goiás. 2009.

SIMIONATO, I. J. Composição química e quantificação de ácidos graxos com ênfase ao ácido linoléico conjugado (CLA) em Leite e derivados. 2008. 114p. Tese (Doutorado em Ciências) Programa De Pós-Graduação Em Química, Universidade Estadual De Maringá, 2008.

VENTURINI, K. S.; SARCINELLI, M. F.; SILVA, L. Características do Leite. Espírito Santo, 2007. Disponível: < http://www.agais.com/telomc/b01007_caracteristicas_leite.pdf>. Acesso em 14/set. 2011.

VIEIRA, J. F. S. Estudo retrospectivo sobre agentes de mastites e sua sensibilidade a antimicrobianos em explorações de montemor-o-velho. 2010. 100p. Dissertação (Mestrado Em Medicina Veterinária) Universidade Técnica De Lisboa, 2010.

VILELA, D.; BRESSAN, M.; CUNHA, A. S. Cadeia de Lácteos no Brasil: restrições ao seu desenvolvimento. Minas $2001 . \quad$ Disponível em: <http://livraria.sct.embrapa.br/liv_resumos/pdf/00066400.pdf>. Acessado e: 08 set. 2011.

ZAFALON, L. F.; FILHO, A. N.; AMARAL, L. A.; et al. Alterações da composição e da produção de leite oriundo quartos mamários de vacas com e sem mastite subclínica de acordo com o estágio e o número de lactações. Arquivo Institucional Biológico. São Paulo, v.72, n.4, p.419-426, out./dez., 2005. 